\title{
Cardiac Inflammation after Ischemia- Reperfusion of the Kidney: Role of the Sympathetic Nervous System and the Renin-Angiotensin System
}

\author{
Karine Panico ${ }^{a}$ Mariana V. Abrahão ${ }^{a}$ Mayra Trentin-Sonoda ${ }^{a, b}$ \\ Humberto Muzi-Filho ${ }^{c, d}$ Adalberto Vieyrac, d,e,f Marcela S. Carneiro-Ramos ${ }^{a}$ \\ aCenter for Natural and Human Sciences, Federal University of ABC, Santo André, São Paulo, Brazil, \\ ${ }^{b}$ Cellular and Molecular Medicine, Faculty of Medicine, University of Ottawa, Ottawa, ON, Canada, \\ 'Carlos Chagas Filho Institute of Biophysics, Federal University of Rio de Janeiro, Rio de Janeiro, \\ Brazil, dNational Center of Structural Biology and Bioimaging/CENABIO, Federal University of Rio \\ de Janeiro, Rio de Janeiro, Brazil, eNational Institute in Science and Technology for Regenerative \\ Medicine/REGENERA, Federal University of Rio de Janeiro, Rio de Janeiro, Brazil, fGraduate Program in \\ Translational Biomedicine/BIOTRANS, Grande Rio University, Duque de Caxias, Brazil
}

\section{Key Words}

Cardiac hypertrophy - Inflammatory cytokines - Renal ischemia/reperfusion

- Renin-angiotensin system • Sympathetic nervous system

\begin{abstract}
Background/Aims: To investigate the role of the sympathetic nervous system (SNS) and reninangiotensin system (RAS) in renal ischemia/reperfusion-induced (I/R) cardiac inflammatory profile. Methods: Left kidney ischemia was induced in male C57BL/6 mice for $60 \mathrm{~min}$, followed by reperfusion for 12 days, and treatment with or without atenolol, losartan, or enalapril. The expression of vimentin in kidney and atrial natriuretic factor (ANF) in the heart has been investigated by RT-PCR. In cardiac tissue, levels of $\beta_{1}$-adrenoreceptors, adenylyl cyclase, cyclic AMP-dependent protein kinase (PKA), noradrenaline, adrenaline (components of SNS), type 1 angiotensin II receptors $\left(A T_{1} R\right)$, angiotensinogen/Ang II and renin (components of RAS) have been measured by Western blotting and HPLC analysis. A panel of cytokines - tumour necrosis factor (TNF- $\alpha$ ), interleukin IL-6, and interferon gamma (IFN- $\gamma$ ) - was selected as cardiac inflammatory markers. Results: Renal vimentin mRNA levels increased by $>10$ times in I/R mice, indicative of kidney injury. ANF, a marker of cardiac lesion, increased after renal I/R, the values being restored to the level of Sham group after atenolol or enalapril treatment. The cardiac inflammatory profile was confirmed by the marked increase in the levels of mRNAs of TNF- $\alpha$, IL- 6 , and IFN- $\gamma$. Atenolol and losartan reversed the upregulation of TNF- $\alpha$ expression, whereas enalapril restored IL-6 levels to Sham levels; both atenolol and enalapril normalized


IFN- $\gamma$ levels. I/R mice showed upregulation of $\beta_{1}$-adrenoreceptors, adenylyl cyclase, PKA and noradrenaline. Renal I/R increased cardiac levels of $A T_{1} R$, which decreased after losartan or enalapril treatment. Renin expression also increased, with the upregulation returning to Sham levels after treatment with SNS and RAS blockers. Angiotensinogen/Ang II levels in heart were unaffected by renal I/R, but they were significantly decreased after treatment with losartan and enalapril, whereas increase in renin levels decreased. Conclusion: Renal I/R-induced cardiac inflammatory events provoked by the simultaneous upregulation of SNS and RAS in the heart, possibly underpin the mechanism involved in the development of cardiorenal syndrome.

(C) 2019 The Author(s). Published by Cell Physiol Biochem Press GmbH\&Co. KG

\section{Introduction}

Close physiological and physio-pathological relationships between the kidney and heart are found that share several functions maintaining homeostasis [1]. Cardiorenal syndrome is characterized by different clinical conditions, with an overlap of cardiac and renal dysfunctions. One subtype of this pathology involves cardiac hypertrophy and failure after acute renal injury (AKI) [1]. AKI frequently leads to the development of chronic kidney disease, and may be associated with ischemia followed by reperfusion (I/R). Ischemia restricts renal blood flow, whereas reperfusion restores the circulation and $\mathrm{O}_{2}$ supply [2]. Ischemic renal damage promotes the release of different inflammatory cytokines that mainly target the heart, and promote cardiovascular alterations following the involvement of the immune system [3].

Inflammation, a systemic condition mediated by multiple factors (cytokines, complement system, etc.) is a non-traditional risk factor in cardiovascular diseases. Recently, however, ischemia, infection and uremic milieu are known to stimulate several inflammatory components in both the kidney and heart $[4,5]$. An association between inflammatory markers and outcomes has been documented in patients with chronic kidney disease [57]. Inflammation may, therefore, serve as a crucial link between increased cardiovascular risk and kidney disease. Nevertheless, the direct involvement of immune or inflammation mediated damage to the pathogenesis of cardiorenal syndromes requires confirmation [8].

An important role of interleukin-6 (IL-6) in the molecular mechanisms underlying the initiation of hypertrophy has been identified [9], a process involving the participation of the sympathetic nervous system (SNS). Moreover, endogenous catecholamines present in immune cells play a central role in the crosstalk between the SNS and immune system [1014]. Trentin-Sonoda et al. [15] showed the participation of cytokines in cardiac lesions after renal I/ $\mathrm{R}$ in mice. The evidence suggests an association between changes in the components of the renin-angiotensin system (RAS), levels of angiotensinogen II $[16,17]$, and cytokines [18], with increased cardiac mass and deleterious cardiac remodelling [19-21]. In the last 2 decades, the relationship between inflammatory cytokines, cardiac natriuretic factors, including atrial natriuretic factor (ANF) and acute cardiac lesions have been reported [22-25]. Of special interest is that important direct and indirect effects of RAS exist, likely mediated by local Ang II and baroreflex, respectively, which enhance SNS activity in the heart $[16,17]$.

We also found - with the use of transthoracic echocardiography, electrocardiogram and action potential recording in the left ventricle - that renal I/R provoked cardiac hypertrophy, increased cardiac wall, augmented myocyte width, and intense electric remodelling [15]. The leading hypothesis herein is that the systemic inflammatory response elicited by renal I/R [15] targets the heart and alters local RAS and SNS, underpinning the mechanism of a PKA-mediated dysregulation of the cardiac cytokine profile. Support for this hypothesis is the observation that the $\beta$-adrenergic stimulus increases a macrophage-mediated immune response in the presence of cAMP as the central mediator [26,27]. With this hypothesis as a basis, we have investigated the responses to losartan (a specific antagonist of the Ang II type 1 receptors $\left(A T_{1} R\right)$ ) and enalapril (an inhibitor of the angiotensin converting enzyme (ACE)) to target RAS. Atenolol, a blocker of $\beta_{1}$-adrenoceptors $\left(\beta_{1}-\mathrm{AR}\right)$ was used to inhibit SNS. 
Materials and Methods

\section{Animals}

All surgical procedures and protocols abided by the Ethical Principles in Animal Research set forth by the Brazilian College of Animal Experimentation, and were approved by the Federal University of ABC Ethics Committee for Animal Research (029/2013 and 030/2013). Male C57BL/6 J mice, 8-week-old (22$28 \mathrm{~g})$, were obtained from the São Paulo University, Institute of Biomedical Sciences (São Paulo, Brazil). Mice were housed in a temperature and light-controlled environment $\quad\left(24^{\circ} \mathrm{C} ; \quad 12 / 12-\mathrm{h}\right.$ light/dark cycle), and had free access to standard mice chow (Purina Agribands) and water until the experiments began.

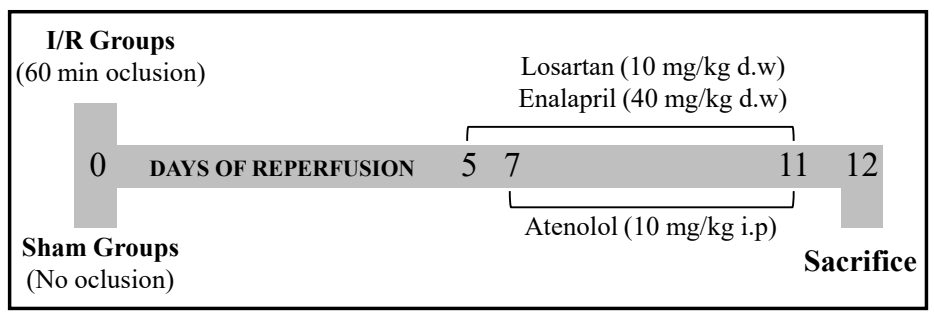

Fig. 1. Flow chart showing chirurgical and pharmacological interventions in the Sham and I/R groups from the ischemia (or not) on day zero until sacrifice after 12 days of reperfusion (horizontal gray bar). Abbreviations: d.w, dissolved in water; i.p, intraperitoneal administration.

Table 1. Primer sequences used for gene expression analysis

\begin{tabular}{|c|c|c|}
\hline Gene & Sense sequence & Antisense sequence \\
\hline Cyclophilin A & AGCATACAGGTCCTGGCATC & AGCTGTCCACAGTCGGAAAT \\
\hline Vimentin & AGATCGATGTGGACGTTTCC & TCCGGTACTCGTTTGACTCC \\
\hline ANF & ATCTGCССТCTTGAAAAGCA & ACACACCACAAGGGCTTAGG \\
\hline TNF- $\alpha$ & ATGGCСТСССТСТСАTСAGT & CTTGGTGGTTTGCTACGACG \\
\hline IL-6 & СТCTGCAAGAGACTTCCATC & СTCTGTGAAGTCTCСTCTCCG \\
\hline INF- $\gamma$ & ACACTGCATCTTGGCTTTGC & CATGTCACCATCСTTTTGCCAG \\
\hline$\beta_{1}$-adrenergic receptor & TGCTCATCGTGGTGGGTAAC & ACCAGCAATCCCATGACCAG \\
\hline Adenylyl cyclase & GGACAGATGCTCTCATCTTG & GGAGGAAGGAGACGGTGAG \\
\hline PKA & AACATCTCGCCACCAGCTAC & GGAGAGTGGGAACCACTACG \\
\hline
\end{tabular}

\section{Renal I/R protocol}

Renal I/R followed a previously described protocol $[15,28]$. Mice were anesthetized with an intraperitoneal injection of ketamine/xylazine (Syntec) (116 and $11.5 \mathrm{mg} / \mathrm{kg}$, respectively). An abdominal incision was made, the left renal pedicle exposed and then occluded with a steel clamp (DL Micof). After 60 min, the steel clamp was removed, and reperfusion began that lasted 12 days. Sham-operated mice had only abdominal incision made, but the pedicle occlusion procedure was not given (Fig. 1).

\section{Pharmacological treatments}

SNS and RAS were blocked using the $\beta_{1}$-adrenoceptor ( $\beta_{1}$-AR) blocker, atenolol (Sigma-Aldrich; 10 $\mathrm{mg} / \mathrm{kg}$ intraperitoneal) [29] the $\mathrm{AT}_{1} \mathrm{R}$ antagonist, losartan (Polydrug Laboratories; $10 \mathrm{mg} / \mathrm{kg}$ ), and the ACE inhibitor, enalapril (Zhejiang Changming Pharmaceutical Co.; $40 \mathrm{mg} / \mathrm{kg}$ ). Both RAS blockers were diluted in drinking water [30-32]. Losartan and enalapril were administered for 7 days and atenolol for 5 days until day 11 of reperfusion (Fig. 1). These time-points were chosen because the onset of elevated circulating cytokines and electrophysiological disturbances occurred at day 8 of reperfusion [15]. The doses of the $\beta_{1}$-AR blocker, the AT $\mathrm{R}$ antagonist, and the ACE inhibitor used were chosen from previous work with these drugs [29-32]. The animals $(n=84)$ were divided in the following 8 groups: (i) Sham; (ii) I/R; (iii) Sham treated with atenolol; (iv) I/R treated with atenolol; (v) Sham treated with losartan; (vi) I/R treated with losartan; (vii) Sham treated with enalapril; and (viii) I/R treated with enalapril. The experimental groups (Sham, I/R) and pharmacological treatments that they received are indicated on the abscissae of the figures.

\section{Gene expression and protein abundance}

RNA from heart ventricles extracted with Trizol@ (Merck) was quantified using NanoDrop Lite ${ }^{\mathrm{TM}}$ spectrophotometer (Thermo Fisher Scientific ${ }^{\odot}$ ). Two $\mu \mathrm{g}$ of total RNA were reverse transcribed to obtain the cDNA used for real-time polymerase chain reaction (PCR) assays (Stratagene ${ }^{\circ}, \mathrm{Mx} 3005 \mathrm{P}$, Agilent Technologies). mRNAs levels for vimentin, ANF, $\beta_{1}$-AR, AC, PKA, renin, TNF- $\alpha$, IL- 6 , and IFN- $\gamma$ were analysed, the primer sequences being shown in Table 1. All the primers have been designed using web-based tools, which ensure high specificity with regard to the desired target (Spidey/Splign, Primer blast, Blast NCBI); we also used the melting curve as an indicator of single fragment amplification. The $2^{-\triangle \Delta C T}$ method was used to calculate changes among the groups. The corresponding figures show the fold changes relative to Sham values. The mean values obtained with Sham were taken as the unitary value, and the individual values from 
the other groups were expressed as fold changes with respect to this value. This also allowed the S.D. of the different Sham values to be calculated.

Total heart ventricle protein was obtained using the radioimmunoprecipitation assay (RIPA) lysis buffer, its concentration being determined with a bicinchoninic acid kit (Thermo Fisher Scientific ${ }^{\odot}$ ). Aliquots of $40 \mu \mathrm{g}$ proteins were resolved by electrophoresis $(5 \%$ stacking/15\% polyacrylamide sodium dodecyl sulphate [SDS] gel), before being transferred to nitrocellulose membranes (Bio-Rad®). The membranes were stained with Ponceau red solution and then washed with TBST (50 mM Tris, $150 \mathrm{mM}$ $\mathrm{NaCl}$, and $2 \%(\mathrm{w} / \mathrm{v})$ Tween-20) for $10 \mathrm{~min}$ at $25-26^{\circ} \mathrm{C}$. After overnight incubation at $4{ }^{\circ} \mathrm{C}$, the membranes were treated with peroxidase-conjugated secondary antibodies diluted in TBST for $1 \mathrm{~h}$ at room temperature. They were finally washed with TBST and incubated with enhanced chemiluminescence detection reagents (Thermo Fisher Scientific $®$ ), the chemiluminescent signals being detected using ChemiDoc (Bio-Rad $®$ ). Band intensity was measured by densitometry using ImageJ software. The antibodies are listed in Table 2. The Santa Cruz sc-7419 polyclonal antibody we used is considered as anti-angiotensin II (Ang II) according to the manufacturer [33, 34], but has been referred to as anti-angiotensinogen antibody by others $[35,36]$, as its molecular mass $(\sim 60 \mathrm{kDa})$ corresponds to that of angiotensinogen. We adopted dual denomination assuming that the levels of both molecules correlate well within cells.

\section{Cardiac catecholamines}

Catecholamines levels were determined in cardiac tissues by the method of Wojicyz et al. [37]. Adrenaline and noradrenaline data (in $\mathrm{ng} / \mathrm{mg}$ wet cardiac tissue) were acquired in a high-performance liquid chromatography (HPLC) system (UltiMate 3000, Thermo Scientific ${ }^{\mathrm{TM}}$ ), according to Mishra et al. [38]. Calculations were carried out using adrenaline and noradrenaline standards (Y0000882 between 50 and $350 \mathrm{ng} / \mathrm{mL}$, and $\mathrm{N} 1100000$ between 300 and $900 \mathrm{ng} / \mathrm{mL}$, respectively), which gave rise to calibrated straight lines).

\section{Analysis of PKA activity}

The activity of PKA was assessed by quantification of the rate of incorporation of $\left[\gamma^{-32} \mathrm{P}\right]$ ATP $\gamma$-phosphoryl group (specific activity of approximately $1.5 \times 10^{11} \mathrm{~Bq} / \mathrm{mmol}$ ) into histone in the absence or presence of PKAi, the specific inhibitor of PKA (final concentration $10 \mathrm{nM}$ ) [39-41]. The activity was expressed in pmol $\mathrm{P} \sim$ histone $\times \mathrm{mg}^{-1} \times \mathrm{min}^{-1}$ ).

\section{Statistical analysis}

Data are expressed as mean \pm standard deviation (SD). The number of animals in each group is presented within the bars. Power analysis $[42,43]$ was used to determine sample size. Calculations were carried out according to Dell et al. [44] by using the equation $n=1+2 \mathrm{C} \times(s / d)^{2}$, where $\mathrm{C}$ is the constant (7.85) for the levels of $\alpha=0.05$ and statistical power $(1-\beta)=0.80$ [44]; and $s$ and $d$ are, respectively, the SD and difference expected in the comparisons between the untreated and the drug-treated animals from the Sham and I/R groups. The minimum was $n=3-4$. The SD and the coefficients of variability intra- and interassay ( $<10$ and $<15 \%$, respectively) were obtained in pilot studies.

Groups were compared using Student's $t$-test or one-factor analysis of variance (ANOVA), followed by Bonferroni test for selected pairs, as indicated in the figure legends. The significance levels have been indicated by the number of asterisks: ${ }^{*} p<0.05,{ }^{* *} p<0.01,{ }^{* * *} p<0.001,{ }^{* * * *} p<0.0001$. Statistical analyses were carried out using GraphPad Prism 6 software (GraphPad Instruments Inc.). 


\section{Cellular Physiology Cell Physiol Biochem 2019;53:587-605 \\ \begin{tabular}{ll|l} 
and Biochemistry & DObli.33594/000000159 & P 2019 The Author(s). Published by \\
\cline { 2 - 3 } & Cell Physiol Biochem Press GmbH\&Co. KG
\end{tabular} \\ Panico et al.: Cardiac Inflammation After Renal Ischemia}

\section{Results}

\section{Renal vimentin $m R N A$ levels after $I / R$}

Real-time PCR was used on kidney samples to measure the gene expression level of vimentin (Fig. 2) as a known molecular marker of renal damage [45], which served for the characterization and validation of other markers [46, 47]. Renal vimentin mRNA levels that were barely detectable in the Sham group increased by 10 -fold in I/R group (Fig. 2A), confirming severe renal impairment. Fig. 2B, C show the results from the experiments that investigated the effect of the 3 treatments on the expression of vimentin mRNA. Evaluation of the extent of lesion in Sham and I/R mice (Fig. 2B) showed that atenolol, losartan and enalapril

Fig. 2. Vimentin mRNA levels in the left kidney from the Sham (empty bars) and I/R (filled bars) C57BL/6J mice. Influence of treatment with atenolol, losartan, or enalapril. Data are expressed as mean \pm SD. The number of experiments using different preparations is indicated within or above each bar. (A) Comparison of renal vimentin mRNA levels between Sham and I/ $R$ mice. Means were compared using Student's t-test; $* * * * \mathrm{p}<0.0001$. (B) Effect of SNS and RAS blockade on renal vimentin mRNA level in Sham mice. Left side: atenolol; ${ }^{* * *} \mathrm{p}<0.0001$, as assessed using Student's t-test. Right side: losartan or enalapril, as indicated on the abscissa; ${ }^{*} \mathrm{p}<0.05,{ }^{* * *} \mathrm{p}<0.001$, as assessed using one-factor ANOVA followed by Bonferroni's test for selected pairs. (C) Effect of blockade of SNS and RAS on renal vimentin mRNA level in I/R mice. Left side: atenolol; **** $\mathrm{p}<0.0001$, as assessed using Student's t-test. Right side: losartan or enalapril, as indicated on the abscissa; ${ }^{* * *} \mathrm{p}<0.001$, as assessed using one-factor ANOVA followed by Bonferroni's test for selected pairs.

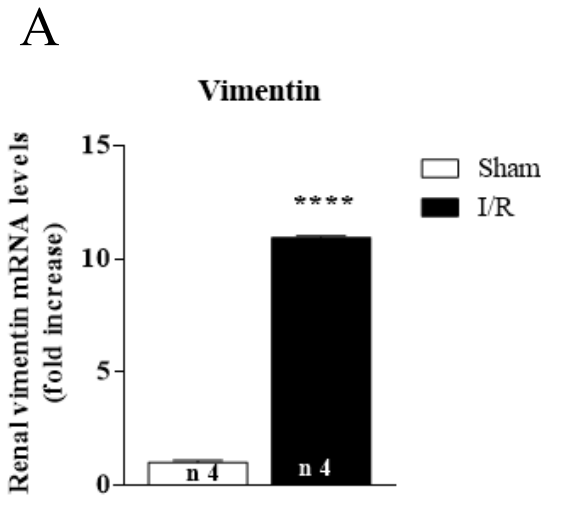

B

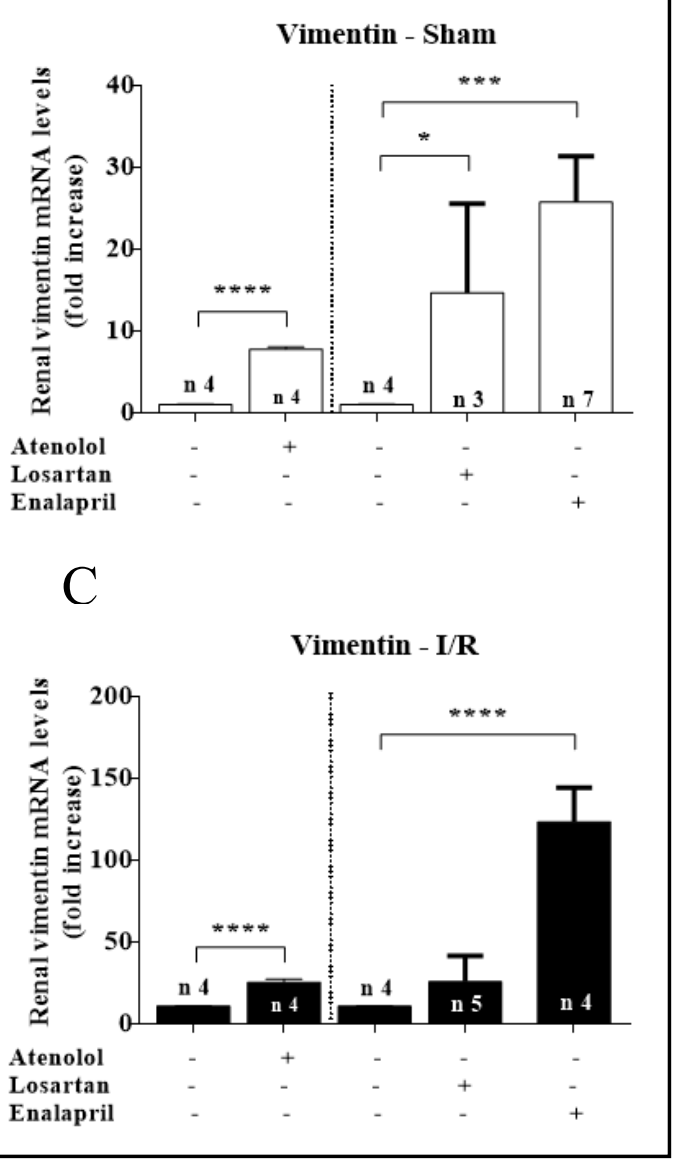


Fig. 3. Cardiac atrial natriuretic factor (ANF) mRNA levels of Sham (empty bars) and I/R (filled bars) mice. Influence of treatment with atenolol (A), losartan, or enalapril (B). Data are expressed as mean $\pm \mathrm{SD}$. The number of experiments using different preparations is indicated within each bar. Mice from each group were treated with or without drug, as indicated on the abscissae. ${ }^{* *} \mathrm{p}<0.01$, ${ }^{* * *} \mathrm{p}<0.001, * * * * \mathrm{p}<0.0001$, as assessed by onefactor ANOVA followed by Bonferroni's test for selected pairs.

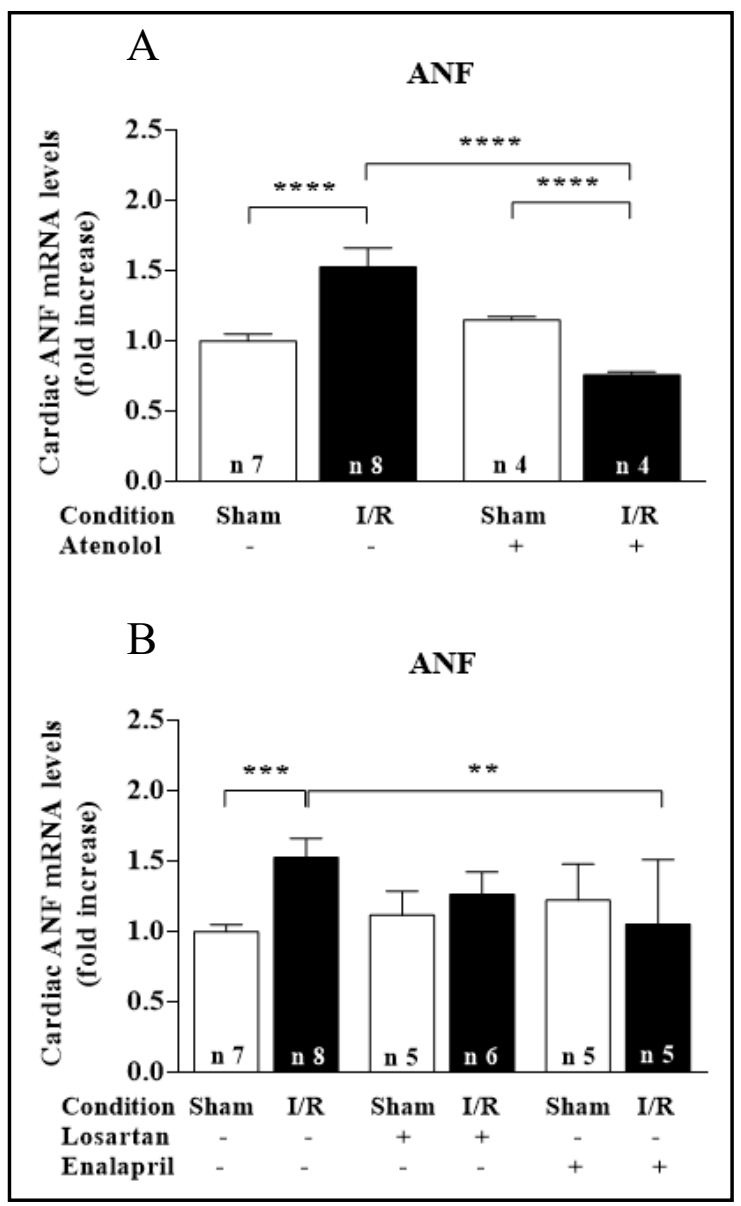

treatment increased vimentin expression 8, 14, and 25 times, respectively, compared with the sham group. Measurement of I/R (Fig. 2C) showed that atenolol and enalapril worsened the severity of the lesion (Fig. 2A). Vimentin expression was twice as high in mice treated with atenolol and 10 times in those receiving enalapril compared with untreated animals. Losartan treatment decreased the marked increase in the level of vimentin after enalapril treatment (Fig. 2C, right part).

\section{Cardiac levels of $A N F$}

ANF mRNA levels increased in the heart after renal I/R, this returning to the level below that observed for Sham group after atenolol treatment (Fig. 3A). No difference in ANF mRNA $\mathrm{l}$ was found between untreated and treated mice receiving losartan or enalapril (Fig. 3B). Enalapril decreased the mRNA level of ANF in the I/R group to that of the Sham group. The data strongly suggest that $\beta_{1}$-AR, ACE and $\mathrm{AT}_{1} \mathrm{R}$ are involved in renal I/R-induced cardiac injury, as evident from the upregulated expression of ANF.

\section{Expression of $\beta_{1}-A R, A C$, and PKA in the heart after renal $I / R$}

AC and PKA are downstream components of the $\beta_{1}$-AR-linked signalling pathway [48]. The severity of renal I/R increased with an increase in the mRNA and protein expression of $\beta_{1}$-AR and AC in the targeted heart. Atenolol treatment restored the mRNA levels of $\beta_{1}$-AR and AC to the levels below those in the Sham group (Fig. 4A-D). Furthermore, AC increased in the heart samples from I/R group, but remained unaffected by atenolol treatment. The upregulated mRNA expression and increase in the level and activity of PKA $\alpha$-catalytic subunit in renal I/R is shown in Fig. 5A-C. In Sham mice, atenolol treatment increased mRNA 


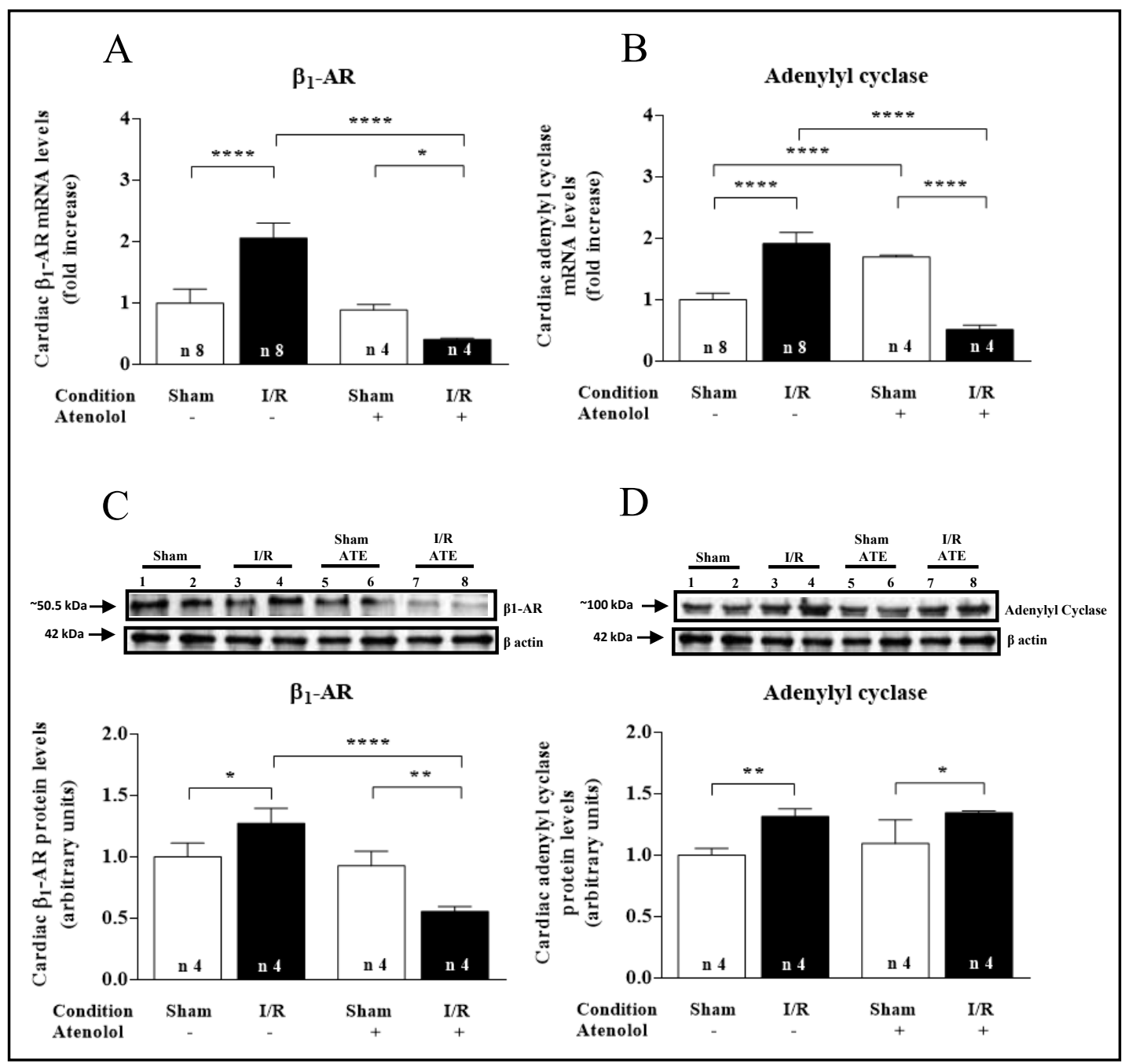

Fig. 4. Cardiac levels of $\beta_{1}$-adrenoreceptors and adenylyl cyclase (mRNA expression and protein abundance) after renal I/R. Data are expressed as mean \pm SD. The number of experiments using different preparations is indicated within each bar. Mice from the Sham (empty bars) and the I/R (filled bars) groups were treated with or without atenolol, as indicated on the abscissae. (A) $\beta_{1}$-AR mRNA. (B) Adenylyl cyclase mRNA. (C) $\beta_{1}$-AR protein abundance. Upper panel: Representative immunodetection for $\beta_{1}$-AR and $\beta$-actin as control for protein loading. ATE: Treatment with atenolol. Lower panel: Graphical representation. (D) Adenylyl cyclase protein abundance. Upper panel: Representative immunodetection and $\beta$-actin as control for protein loading. Lower panel: Graphical representation. Differences were assessed using one-factor ANOVA followed by Bonferroni's test for selected pairs. ${ }^{*} \mathrm{p}<0.05,{ }^{* *} \mathrm{p}<0.01,{ }^{* * * *} \mathrm{p}<0.0001$.

(Fig. 5A) and protein (Fig. 5B) of PKA, but downregulated enzyme activity (Fig. 5C). In I/R, treatment with atenolol decreased PKA gene expression (Fig. 5A) and activity (Fig. 5C), with no effect on the protein level of PKA (Fig. 5B). 
Fig. 5. Cardiac cAMP-dependent protein kinase (PKA). mRNA expression, protein abundance, and enzyme activity after renal I/R. Data are expressed as mean \pm SD. The number of experiments using different preparations is indicated within each bar. Mice from Sham and I/R groups were treated with or without atenolol, as indicated on the abscissae. (A) PKA mRNA. (B) PKA catalytic -subunit abundance. Upper panel: Representative immunodetection for PKA and $\beta$-actin as control for protein abundance. ATE: Treatment with atenolol. Lower panel: Graphical representation. (C) PKA activity. ${ }^{*} \mathrm{p}<0.05$, ${ }^{* *} \mathrm{p}<0.01,{ }^{* * *} \mathrm{p}<0.001,{ }^{* * * *} \mathrm{p}<0.0001$, as assessed using one-factor ANOVA followed by Bonferroni's test for selected pairs.

\section{Noradrenaline Expression in Heart after Renal I/R}

The levels of catecholamines in the heart tissues of Sham and I/R mice after 12 days of renal reperfusion were measured (Fig. 6). Noradrenaline was augmented in the $I / R$ group compared to the Sham group in the absence of atenolol, and higher levels were in Sham and I/R mice treated with atenolol (Fig. 6A). No changes were observed in adrenaline (Fig. 6B).

Profile of different components of the cardiac renin-angiotensin system after renal $I / R$

Cardiac levels of $\mathrm{AT}_{1} \mathrm{R}$ and angiotensinogen/Ang II are given in Fig. 7. The level of $\mathrm{AT}_{1} \mathrm{R}$ increased by $30 \%$ in the I/R group than in the Sham group, and losartan and enalapril treatment had no effect on the Sham group. Both losartan and enalapril decreased significantly the level of the receptor in I/R mice (Fig. 7A). Angiotensinogen/Ang II levels were significantly lower in the receptor in the I/ $R$ group after treatment with receptor blocker and ACE inhibitor, whereas no effects were seen in the Sham animals (Fig. 7B).

Renal I/R significantly increased the expression of renin mRNA by $>7$-fold (Fig. 8). Treatments with atenolol, losartan and enalapril resulted in the restoration renin mRNA to normal values. Treatment of the Sham group with atenolol significantly increased the mRNA level of renin.

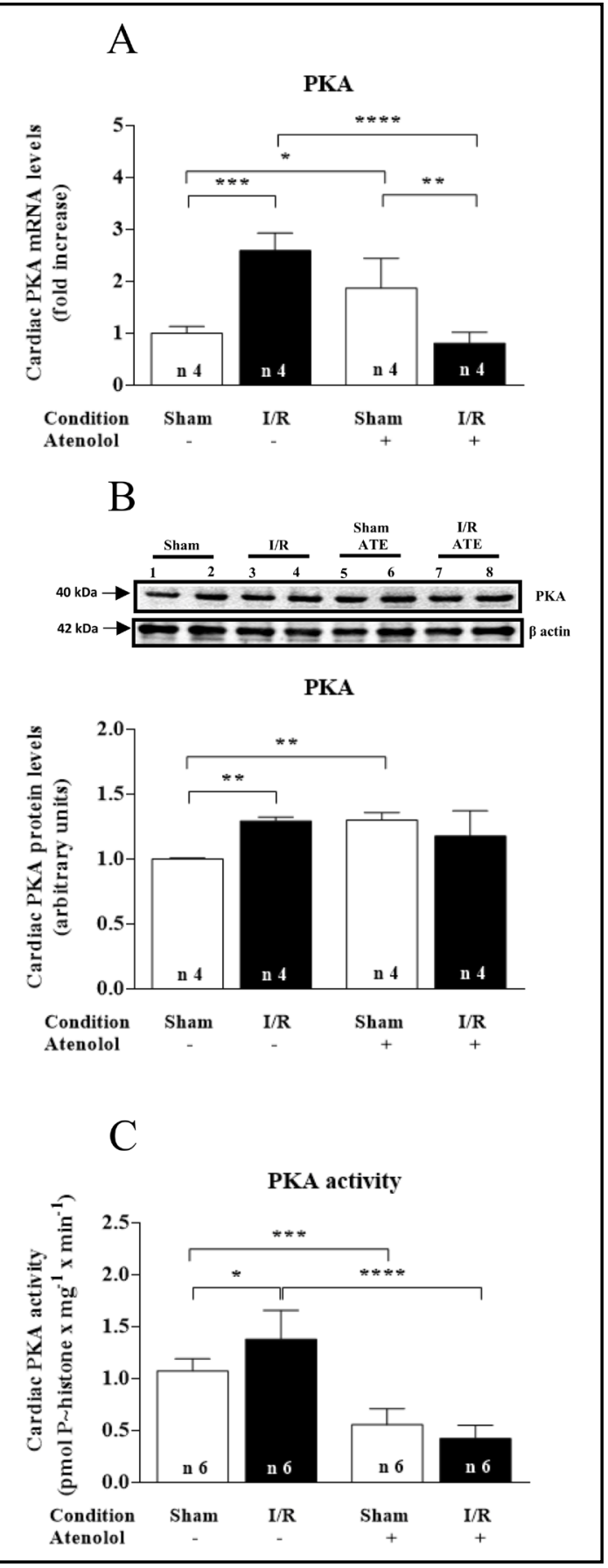


Fig. 6. Catecholamine levels in the heart tissue. Data are expressed as mean \pm SD. The number of experiments using different preparations is indicated within each bar. Mice from Sham and I/R groups were treated with or without atenolol, as indicated on the abscissae. (A) Noradrenaline levels. (B) Adrenaline levels. ${ }^{* * * *} \mathrm{P}<0.0001$ in $\mathrm{A}$ but no statistical differences in $B$, as assessed by one-factor ANOVA followed by Bonferroni's test for selected pairs.

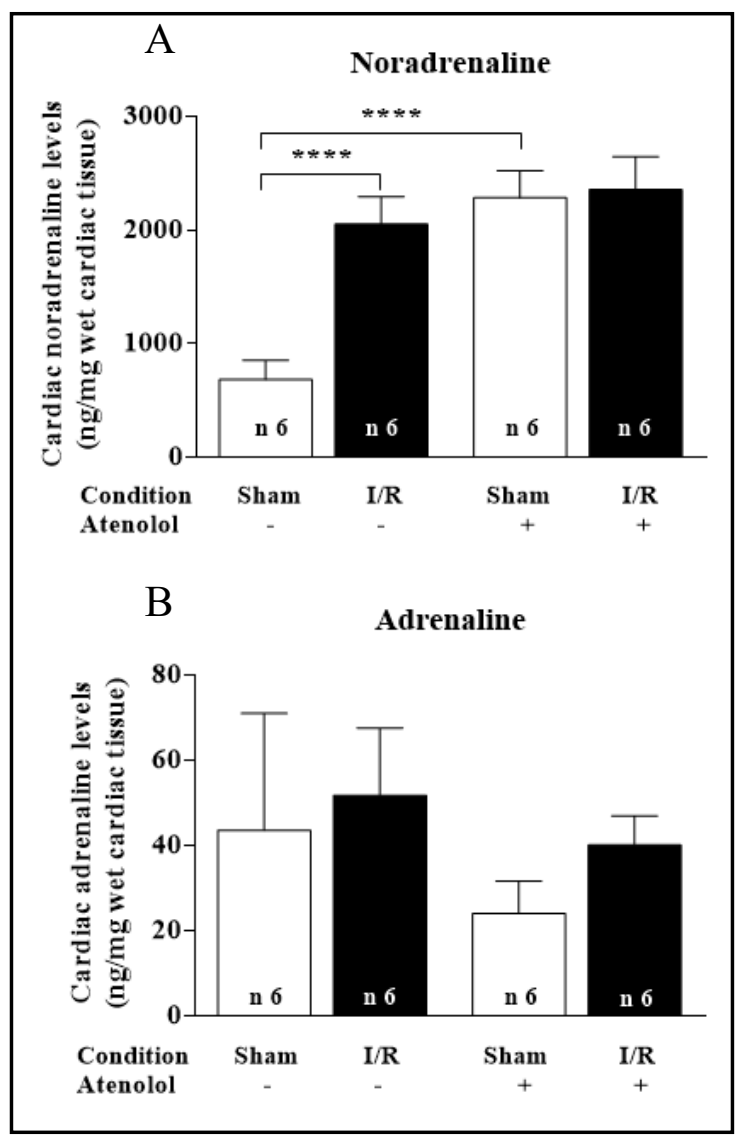

\section{Expression of inflammatory cytokines in the heart after renal $I / R$}

Fig. 9 shows the expression of the 3 key inflammatory cytokines in the heart tissue after renal I/R; in all there was a highly raised level:- $250 \%$ for TNF- $\alpha$ (Fig. 9A), 580\% for IL-6 (Fig. 9B) and $470 \%$ for IFN- $\gamma$ (Fig. 9C). The response of theses pharmacological treatments were different. In the case of TNF- $\alpha$, the increase was reduced by atenolol and losartan, whereas the increase of IL- 6 was attenuated only by enalapril. The augmented IFN- $\gamma$ responded to atenolol and enalapril treatment.

\section{Discussion}

Renal I/R, the key pathophysiological event in AKI, is associated with high mortality rates $[49,50]$. We have developed an experimental model to study the molecular mechanisms underlying SNS and RAS in cardiac lesions after renal I/R.

The damage induced by renal I/R was evident from increased mRNA expression of vimentin (Fig. 2), one of the most important molecular markers of renal damage [45], and other functional and structural markers, such as epidermal growth factor, proliferating cell antigen, c-Fos and clusterin [46, 47]. Trentin-Sonoda et al. [15] showed that: (i) I/R increased plasma levels of the markers of lesions, namely creatinine and urea, (ii) I/R induces renal parenchymal alterations detected by proton density magnetic resonance, as well as by signs of parenchymal edema. The renal lesion worsened following blockade of $\beta 1$-AR with atenolol, indicating that renal SNS signalling is essential to prevent renal damage, an idea supported by the observation that the $\beta$-AR blocker induced vimentin expression in Sham mice. These puzzling observations about the kidney are suggestive of SNS-activated mechanisms similar to those beneficial ones described - or believed to occur - in ischemic preconditioning 
Fig. 7. Ang II type 1 receptor density and angiotensinogen/Ang II level in heart tissue after renal I/R. Data are expressed as mean \pm SD. The number of experiments using different preparations is indicated within or above each bar. Mice from Sham (empty bars) and I/R (filled bars) groups were treated with or without different drugs, as indicated on the abscissae. (A) $\mathrm{AT}_{1} \mathrm{R}$ abundance. Upper panel: Representative immunodetection for $\mathrm{AT}_{1} \mathrm{R}$ and glyceraldehyde-3-phosphate dehydrogenase (GAPDH) as protein loading control. Lower panel: Graphical representation. (B) Angiotensinogen (AGT)/Ang II abundance and GAPDH as protein loading control. Upper panel: Representative immunodetection for AGT/Ang II and GAPDH as protein loading control. Lower panel: Graphical representation. ${ }^{* *} \mathrm{p}<0.01,{ }^{* * *} \mathrm{p}<0.001$, ${ }^{* * * *} \mathrm{p}<0.0001$, as assessed using onefactor ANOVA followed by Bonferroni's test for selected pairs. Upper bands in $A(a, b, c)$ and $B(g, h, i)$ show for comparison 3 different representative immunodetections developed in separate experiments. Lower bands in $A$ and $B(d, e, f)$ show loading controls, which were the same for $A$ and $B$.

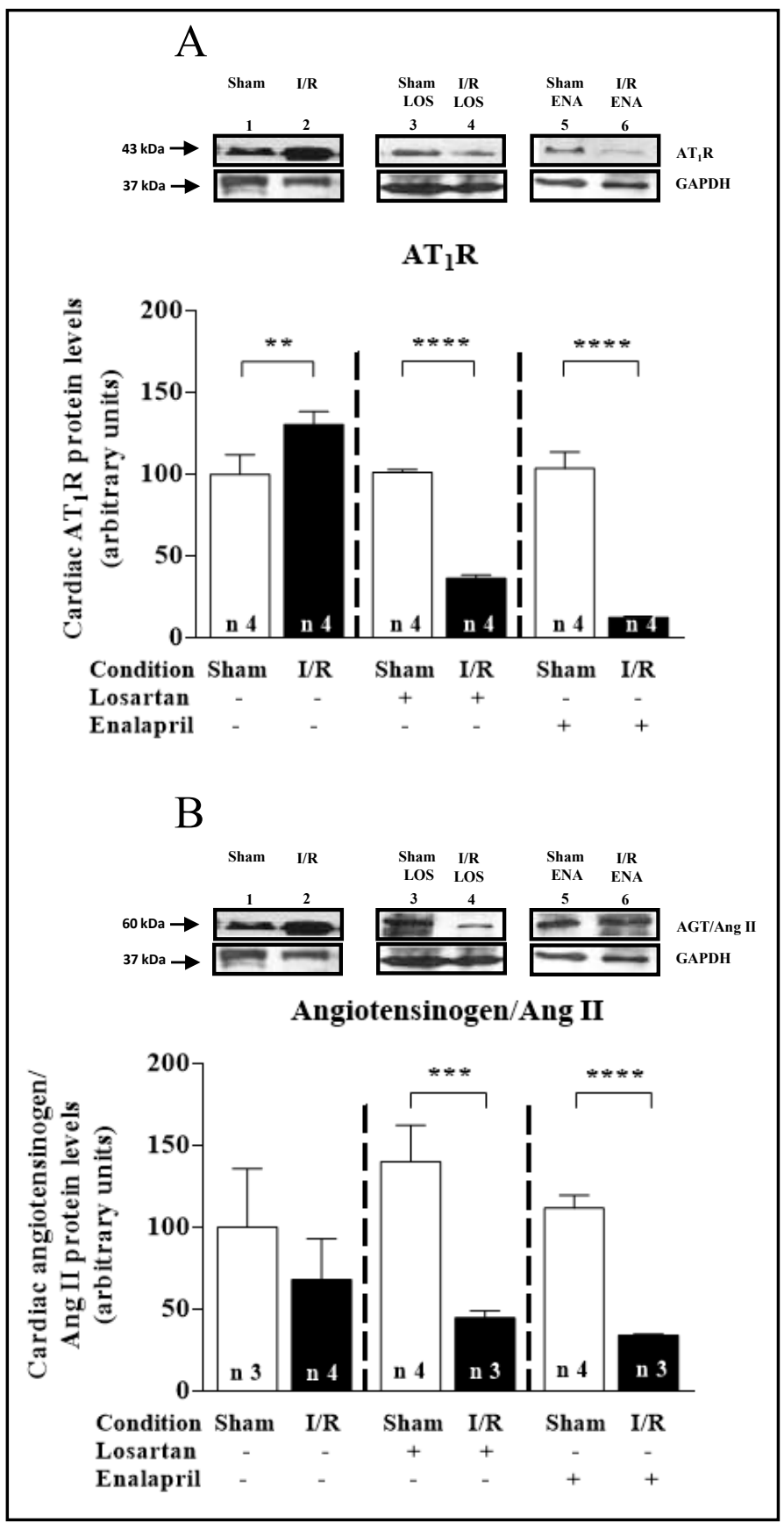

against I/R injury [51]. These effects elicited by SNS activation probably involve integrated central and peripheral mechanisms; they could increase local NO release [52], secretion of prostaglandins [53], or even increase perfusion pressure [54].

The results of the pharmacological manipulation of RAS suggest that Ang II formation is also important in minimizing, but not avoiding, ischemic lesion. As enalapril, but not losartan, increased the vimentin level, the signalling process downstream of renal $\mathrm{AT}_{1} \mathrm{R}$ would not be altered in the injured kidney in the presence of adequate levels of Ang II. As no difference was found in plasma levels of Ang II between Sham and I/R mice (range 20-40 ng/ $\mathrm{mL}$ ), the integrity of local RAS (but not of systemic RAS) seems to be important in avoiding the worsening of I/R-induced renal lesions. The beneficial effects of Ang II are in line with those noted by Wenzel et al. [55]. Four possible mechanisms can be posited. First, Ang II 
Fig. 8. Renin mRNA levels in the heart tissue after renal I/R. Data are expressed as mean \pm SD. The number of experiments using different preparations is indicated within or above each bar. Mice from Sham (empty bars) and I/R (filled bars) groups were treated with or without different drugs, as indicated on the abscissae. (A) Comparison of cardiac renin mRNA levels between Sham and I/R mice. Means were compared using Student's t-test; $* * * * \mathrm{p}<0.0001$. (B) Effect of SNS and RAS blockade on cardiac renin mRNA level from Sham mice. Left side: atenolol; ${ }^{* * *} \mathrm{p}<0.001$, as assessed using Student's t-test. Right side: losartan or enalapril, as indicated on the abscissa; ${ }^{*} \mathrm{p}<0.05$, as assessed using one-factor ANOVA followed by Bonferroni's test for selected pairs. (C) Effect of blockade of SNS and RAS on cardiac renin mRNA level in I/R mice. Left side: Atenolol; ${ }^{* * * *} \mathrm{p}<0.0001$, as assessed using Student's t-test. Right side: Losartan or enalapril, as indicated on the abscissa; ${ }^{* * * *} \mathrm{p}<0.0001$, as assessed using one-factor ANOVA followed by Bonferroni's test for selected pairs.

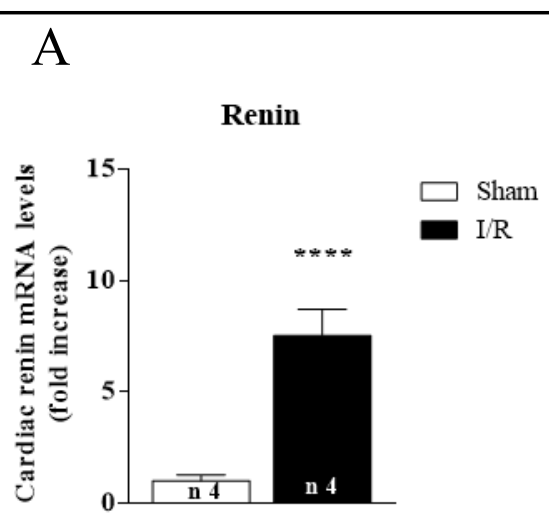

$\mathrm{B}$
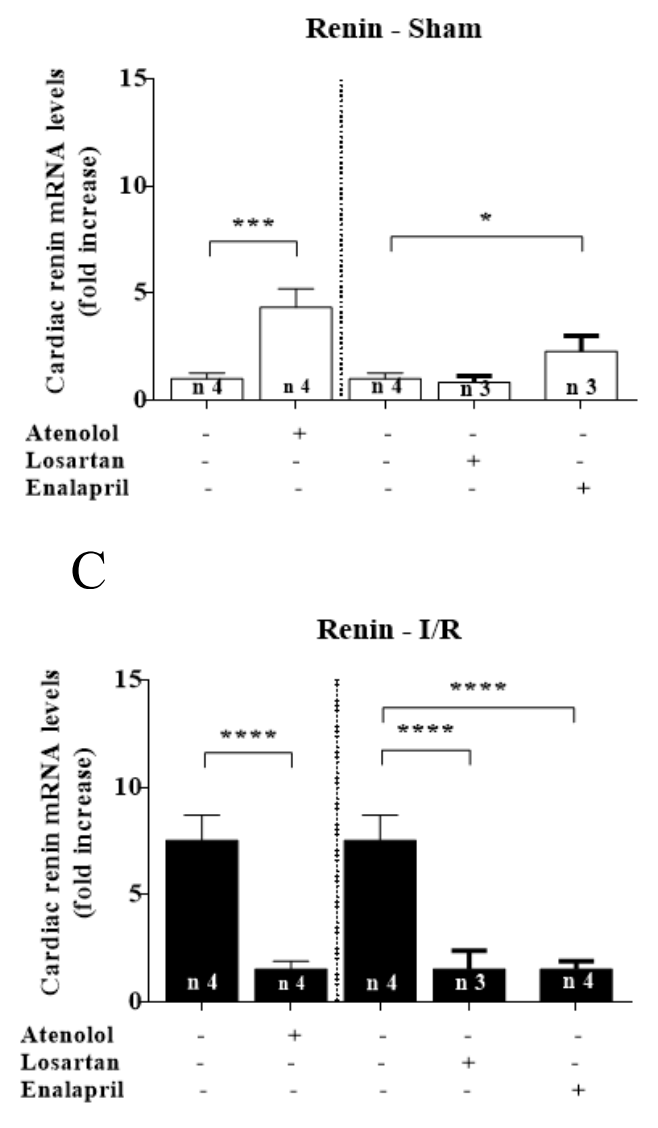

decreases the inflow of inflammatory mediators owing to its vasoconstrictor effects on renal blood flow, thereby reducing the inflow of disease activators [55]. Second, Ang II maintains endothelial nitric oxide levels in the renal tissue $[56,57]$. Third, high local concentrations of Ang II activate the low-affinity $\mathrm{AT}_{2} \mathrm{R}$-linked signalling pathway, which is opposite to that of $\mathrm{AT}_{1} \mathrm{R}$ [58]. Finally, a fourth mechanism could involve activation of the ACE2/Ang-(1-7)/Mas receptor axis, which protects against vascular and inflammatory injuries [59-62].

The scenario seems opposite when considering the molecular marker of cardiac injury ANF (Fig. 3). Inhibition of the increase in the ANF mRNA levels by atenolol, losartan and enalapril supports the view that both SNS and RAS are involved in renal I/R-induced cardiac lesion. Thus, blocking SNS or RAS may be beneficial for improving the structure and function of the injured heart. In a rat model of congestive heart failure after infarction, administration 
Fig. 9. Inflammatory profile in cardiac tissue after renal I/R. Gene expression for TNF- $\alpha$, IL-6, and IFN- $\gamma$ was determined in Sham (empty bars) and I/R (filled bars) mice were treated with or without atenolol, losartan, or enalapril, as indicated on the abscissae. (A) TNF- $\alpha$ mRNA. (B) IL-6 mRNA. (C) IFN- $\gamma$ mRNA. Data are mean \pm SD. Differences were assessed using one-factor ANOVA followed by Bonferroni's test for selected pairs. ${ }^{*} \mathrm{p}<0.05,{ }^{* *} \mathrm{p}<0.01,{ }^{* * *} \mathrm{p}<0.001,{ }^{* * * *}$ $\mathrm{p}<0.0001$.
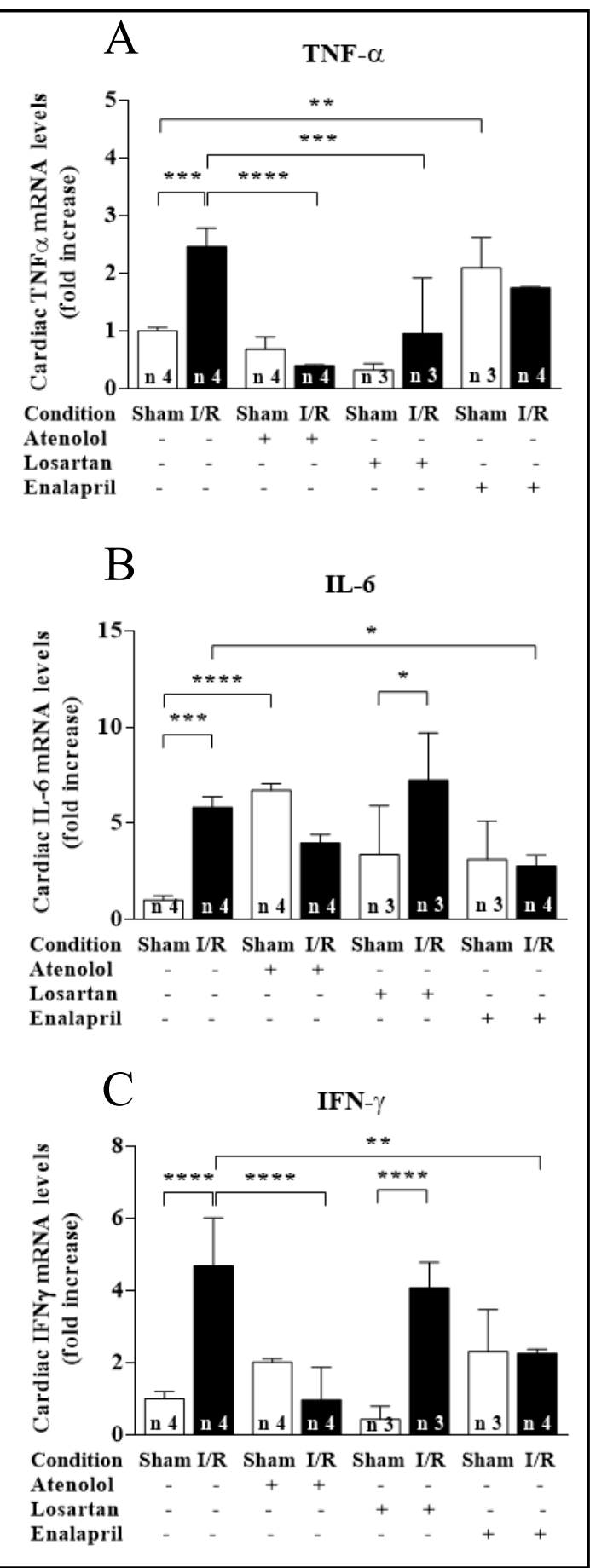

of atenolol or propranolol improved cardiac function and late myofibrillar remodelling [63]. RAS blocking likewise prevented myocardial I/R lesion and post-infarction remodelling [64]. The influence of atenolol and enalapril might be associated to the fact that local Ang II and sympathetic nerve activation stimulate ANP synthesis in myocytes. In a positive feedback situation, ANP stimulates RAS through signaling mechanisms involving mobilization of intracellular $\mathrm{Ca}^{2+}$ and activation of protein kinase $\mathrm{C}[65,66]$. Moreover, ANP, RAS inhibition and $\beta$-sympathetic nerve blocking modulate cytokine receptor expression and cytokine release in the heart as the result of the altered neurohumoral-immune cross-talk that occurs during cardiac remodeling (revised in [67]). 
The high levels of noradrenaline in heart tissue ensure the recruitment of the agonist to high levels to maintain the permanent activation status of the pathway (Fig. 6). In addition, the fact that the noradrenaline, but not adrenaline, level increased without atenolol treatment may provide clues regarding the origin of the raised catecholamines. This observation seems to be a consequence of renal I/R-stimulated release of noradrenaline from the sympathetic nerve terminals in the cardiac tissue $[68,69]$, and not owing to the uptake from the plasma. During global SNS hyperactivation, the increase of adrenaline in the plasma arises from sympathoadrenal activation [70]. Renal I/R-induced cardiac adrenergic activation involves a transmitter that is more selective for $\beta_{1}$-AR than for $\beta_{2}-A R$ [71], and may be the cause for hyperactivity in the pathway.

In terms of mechanisms, Fig. 4, 5 show the intriguing effects on the $\beta_{1}$-AR signalling pathway, which is selectively modified by renal I/ $R$ and can differentially respond to receptor blockade by atenolol. The renal I/R-induced increase in cardiac mRNA levels of $\beta_{1}$-AR, AC, and PKA is indicative of a global synchronous transcription stimulation encompassing the 3 components of the signalling cascade, which is abolished after treatment with the receptor blocker. Conversely, atenolol increased the mRNA levels of AC and PKA, which could be a normal physiological compensatory response in the case of decreased $\beta_{1}$-AR activity. Atenolol can upregulate or downregulate different genes [72], a property that could be different in Sham and I/R mice.

The abundance of the 3 proteins $\left(\beta_{1}-\mathrm{AR}, \mathrm{AC}\right.$, and $\left.\mathrm{PKA}\right)$ increased to about $30 \%$ in $\mathrm{I} / \mathrm{R}$ mice compared to Sham mice, which shows the synchronous influence of renal lesion on the translation of the proteins associated with the cardiac $\beta_{1}$-AR signalling cascade. The fact that atenolol decreases the $\beta_{1}$-AR levels, but not the enzymes, suggests that the specific regulatory elements associated with these proteins in the heart are differentially activated/deactivated by renal I/R during the translation of their respective mRNAs. Several translational regulatory elements, with specific targets in physiological and pathological conditions, influence the number of protein molecules per mRNA molecule $[73,74]$.

The increased activity of SNS in the heart after renal I/R is accompanied with an upregulated expression of 2 components of the local RAS, as evident from the protein levels (AT $\mathrm{R}_{1}$ and angiotensinogen/Ang II) (Fig. 7) or mRNA levels (renin) (Fig. 8). An increase in cardiac AT ${ }_{1} \mathrm{R}$ protein indicates that renal I/R injury upregulates the local cardiac RAS. The fact that the receptor density remained unmodified in the Sham mice and was low after losartan or enalapril treatment in I/R indicates that the actions of the drugs become evident in the presence of the humoral factors that are released following renal injury. One of these factors could be TNF- $\alpha$, which is important in the progress of the I/R injury in mice [75], shown by the high levels in the plasma of our animal model [15]. The $\sim 200 \%$ increase in TNF- $\alpha$ level in the heart several days after I/R supports this view. TNF- $\alpha$ might act by enhancing the rate of $\mathrm{AT}_{1} \mathrm{R}$ transcription, as demonstrated in cardiac fibroblasts after postmyocardial infarction remodelling [76]. The same humoral I/R-induced environment seems to favour the similar effects of losartan and enalapril because the drugs decrease in parallel both RAS components.

Renal I/R-induced 6-fold increase in cardiac renin mRNA level (Fig. 8), which was restored to Sham levels after atenolol treatment - as also losartan and enalapril - is indicative of a regulatory effect of SNS on RAS signalling. Since cardiac angiotensinogen remained unmodified by renal I/R (Fig. 7), it is possible that renal I/R-induced upregulation of renin ensures the maintenance of Ang II levels and the short-term pathological structural modifications encountered in this model [15]. The increased level of renin in heart may be a consequence of the humoral signals resulting from renal I/R, or could be potentiated by activated SNS [77]. RAS stimulation results in the creation of a vicious circle that culminates in cardiac lesions in several pathologies [17]. The possibility that should also be considered is that increased cardiac renin results from increased binding and/or uptake of circulating prorenin and renin, which could be favoured by the same factors [78, 79].

Elevated cytokine levels in the plasma and distant organs, such as liver, lung [80], gut [81], brain [82] and other organs besides the heart [83], have been reported after renal I/R 


\section{Cellular Physiology Cell Physiol Biochem 2019;53:587-605 \\ \begin{tabular}{ll|l} 
and Biochemistry & $\begin{array}{l}\text { DOl: 10.33594/000000159 } \\
\text { Published online: } 20 \text { September } 2019\end{array}$ & $\begin{array}{l}\text { O } 2019 \text { The Author(s). Published by } \\
\text { Cell Physiol Biochem Press GmbH\&Co. KG }\end{array}$ \\
\cline { 2 - 3 } & Paico al Ca
\end{tabular} \\ Panico et al.: Cardiac Inflammation After Renal Ischemia}

(reviewed by [84]). The raised cardiac levels of TNF- $\alpha$ and IFN- $\gamma$ (Fig. 9) matched those we previously reported in the plasma after 5 days of I/R [15], and increased expression of IL-6 occurs in the myocardium of subjects with cardiac dysfunction [85]. Therefore, these molecules may be considered as diverse and appropriate markers of inflammation of the heart in this renal I/R model, and their levels may increase in response to the local increase in $\beta_{1}$-adrenergic and RAS signalling [77, 86-88]. The relationship with $\beta_{1}$-AR-mediated signalling seems to be selective. Atenolol restores the levels of TNF- $\alpha$ and IFN- $\gamma$, but not IL-6; IL-6 levels were also shown to increase in Sham mice treated with blocker. These differences in the anti-inflammatory effect of atenolol could be attributed to a specific cytokinemodulated microenvironmental profile that modulates the sympathoimmune interactions in the tissue in different ways [88]. The differential responses of the 3 cytokines after losartan and enalapril treatment also point to the specific dependencies of each cytokine, with respect to different components of the RAS signalling cascade. High Ang II levels stimulate different arrays of pro-inflammatory cytokines in the kidney, leading to progressive renal injury [89]; a similar effect can be observed in the heart after renal I/R.

Finally, because blood pressure alterations after renal I/R could play a role as a connector of the renal-cardiac axis, we evaluated this parameter before and following I/R. Our studies did not reveal changes in systolic blood pressure even after the 12 days post-surgery. Indeed, blood pressure and heart rate post-surgery averaged $98 \pm 5 \mathrm{mmHg}$ and $584 \pm 31 \mathrm{bpm}$ in Sham animals $(n=5)$ and $99 \pm 4 \mathrm{mmHg}$ and $581 \pm 21 \mathrm{bpm}$ following I/R $(n=3)(\mathrm{P}>0.05$ when each parameter was compared between the Sham and the I/R groups). These data indicate that the observed cardiac alterations are independent of blood pressure changes after renal I/R injury. Even though a late and sustained increase in losartan- and enalaprilsensitive blood pressure can occur at the early stages of heart injury after renal I/R, cardiac hypertrophy [15] is independent of blood pressure. Cardiac hypertrophy, however, has been frequently associated with hypertension in animals [90] and humans [91]. However, several reports also show that cardiomyocyte hypertrophy is independent of blood pressure in animals and humans in some cases [92-95]. Interestingly, a recent study has demonstrated that Ang II-induced hypertension and cardiac hypertrophy are differentially mediated by TLR3- and TLR4-signaling pathways [96], which are involved in renal I/R-induced cardiac damage [15]. It is possible that activation of these pathways is not synchronous, and for this reason, the onset of hypertension could be delayed.

\section{Limitations of this Study}

The pharmacological compounds used may have overlapping consequences and the targeted pathways could be mutually interacting, which is one limitation. The mechanism by which losartan and enalapril decrease $\mathrm{AT}_{1} \mathrm{R}$ expression needs to be fully elucidated, though it could be explained by the consequence of an upstream decrease of renin and internalization/ degradation of the inactivated receptor.

\section{Conclusion}

The results clearly demonstrate that both SNS and RAS have central roles in the mechanisms underlying upregulation in the expression of inflammatory cytokines in the heart after renal I/R. They support the proposition that renal I/R-induced cardiac inflammatory events provoked by the simultaneous upregulation of both systems in the heart are central in the mechanism involved in the development of a cardiorenal syndrome after a primary kidney lesion. 


\section{Cellular Physiology Cell Physiol Biochem 2019;53:587-605

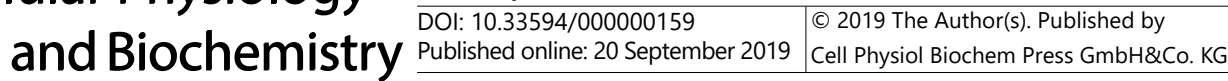 \\ Panico et al.: Cardiac Inflammation After Renal Ischemia}

\section{Acknowledgements}

We thank Dra. Daniele Ribeiro de Araújo for helping us with the dosages of catecholamines using UHPLC. The English style of the first version of this article was corrected by Editage (Brazil). The second version was corrected by BioMedES (United Kingdom) (www.biomedes. biz). The PROCAD/CAPES grant, number 88887.124150/2014-00, is acknowledged.

Author contributions: MSC-R conceived, designed and supervised the research, and obtained funding. KP, MVA, MTS and HM-F acquired, analyzed and interpreted the data and carried out statistical analyses. KP and MSC-R drafted the manuscript. KP, HM-F, AV and MSC-R analyzed and interpreted the data, performed the statistical analyses and wrote the manuscript. All authors read and approved the manuscript.

Funding: The present study was funded by FAPESP (Fundação de Amparo à Pesquisa do Estado de São Paulo No 2008/10175-4 and 2015/19107-5).

\section{Disclosure Statement}

The authors declare no conflicts of interest.

\section{References}

1 Di Lullo L, Bellasi A, Barbera V, Russo D, Russo L, Di Iorio B, Cozzolino M, Ronco C: Pathophysiology of the cardio-renal syndromes types 1-5: An uptodate. Indian Heart J 2017;69:255-265.

2 Doi K, Noiri E: Mitochondrial dysfunction in cardiorenal syndrome. Antioxid Redox Signal 2016;25:200207.

3 Liu D, Shang H, Liu Y: Stanniocalcin-1 protects a mouse model from renal ischemia-reperfusion injury by affecting ROS-mediated multiple signaling pathways. Int J Mol Sci 2016;17:1051.

4 Rysavá R, Kalousová M, Zima T, Dostál C, Merta M, Tesar V: Does renal function influence plasma levels of advanced glycation and oxidation protein products in patients with chronic rheumatic diseases complicated by secondary amyloidosis? Kidney Blood Press Res 2007;30:1-7.

5 Kingma JG, Simard D, Rouleau JR, Drolet B, Simard C: The physiopathology of cardiorenal syndrome: A review of the potential contributions of inflammation. J Cardiovasc Dev Dis 2017;4:21.

6 Menon V, Greene T, Wang X, Pereira AA, Marcovina SM, Beck GJ, Kusek JW, Collins AJ, Levey AS, Sarnak MJ: $\mathrm{C}$-reactive protein and albumin as predictors of all-cause and cardiovascular mortality in chronic kidney disease. Kidney Int 2005;68:766-772.

7 Soriano S, González L, Martín-Malo A, Rodríguez M, Aljama P: C-Reactive protein and low albumin are predictors of morbidity and cardiovascular events in chronic kidney disease (CKD) 3-5 patients. Clin Nephrol 2007;67:352-57.

8 Virzì GM, Torregrossa R, Cruz DN, Chionh CY, de Cal M, Soni SS, Dominici M, Vescovo G, Rosner MH, Ronco C: Cardiorenal syndrome type 1 may be immunologically mediated: a pilot evaluation of monocyte apoptosis. Cardiorenal Med 2012;2:33-42.

9 Jougasaki M, Tachibana I, Luchner A, Leskinen H, Redfield MM, Burnett Jr JC: Augmented cardiac cardiotrophin-1 in experimental congestive heart failure. Circulation 2000;101:14-17.

10 Victor RG, Mark AL: Interaction of cardiopulmonary and carotid baroreflex control of vascular resistance in humans. J Clin Invest 1985;76:1592-1598.

11 Elenkov IJ, Wilder RL, Chrousos GP, Vizi ES: The sympathetic nerve - an integrative interface between two supersystems: the brain and the immune system. Pharmacol Rev 2000;52:595-638.

12 Nance DM, Sanders VM: Autonomic innervation and regulation of the immune system (1987-2007). Brain Behav Immun 2007;21:736-745.

13 Grisanti LA, Woster AP, Dahlman J, Sauter ER, Combs CK, Porter JE: $\alpha_{1}$-adrenergic receptors positively regulate toll-like receptor cytokine production from human monocytes and macrophages. J Pharmacol Exp Ther 2011;338:648-657. 
14 Gordan R, Gwathmey JK, Xie LH: Autonomic and endocrine control of cardiovascular function. World J Cardiol 2015;7:204-214.

15 Trentin-Sonoda M, Silva RC, Kmit FV, Abrahão MV, Cahli GM, Brasil GV, Muzi-Filho H, Silva PA, Tovar-Moll FF, Vieyra A, Medei E, Carneiro-Ramos MS: Knockout of toll-like receptors 2 and 4 prevents renal ischemiareperfusion-induced cardiac hypertrophy in mice. PloS One 2015;10:e0139350.

16 Goldsmith SR: Angiotensin II and sympathoactivation in heart failure. J Card Fail 1999;5:139-145.

17 Stupin A, Drenjancevic I, Rasic L, Cosic A, Stupin M: A cross-talk between the renin-angiotensin and adrenergic systems in cardiovascular health and disease. SEEMEDJ 2017;1:90-107.

18 Chaar LJ, Alves TP, Batista Jr AM, Michelini LC: Early training-induced reduction of angiotensinogen in autonomic areas-the main effect of exercise on brain renin-angiotensin system in hypertensive rats. PloS One 2015;10:e0137395.

19 Crowley SD, Gurley SB, Herrera MJ, Ruiz P, Griffiths R, Kumar AP, Kim HS, Smithies O, Le TH, Coffman TM: Angiotensin II causes hypertension and cardiac hypertrophy through its receptors in the kidney. Proc Natl Acad Sci U S A 2006;103:17985-17990.

20 Kumar R, Singh VP, Baker KM. The intracellular renin-angiotensin system in the heart. Curr Hypertens Rep 2009;11:104-110.

21 Silva Jr SD, Jara ZP, Peres R, Lima LS, Scavone C, Montezano AC, Touyz RM, Casarini DE, Michelini LC: Temporal changes in cardiac oxidative stress, inflammation and remodeling induced by exercise in hypertension: role for local Angiotensin II reduction. PloS One 2017;12:e0189535.

22 Maeda K, Tsutamoto T, Wada A, Mabuchi N, Hayashi M, Tsutsui T, Ohnishi M, Sawaki M, Fujii M, Matsumoto T, Kinoshita M: High levels of plasma brain natriuretic peptide and interleukin- 6 after optimized treatment for heart failure are independent risk factors for morbidity and mortality in patients with congestive heart failure. J Am Coll Cardiol 2000;36:1587-1593.

23 Liang F, Kapoun AM, Lam A, Damm DL, Quan D, O'Connell M, Protter AA: B-type natriuretic peptide inhibited Angiotensin II-stimulated cholesterol biosynthesis, cholesterol transfer, and steroidogenesis in primary human adrenocortical cells. Endocrinology 2007;148:3722-3729.

24 Meirovich YF, Veinot JP, Bold MLK, Haddad H, Davies RA, Masters RG, Hendry PJ, de Bold AJ: Relationship between natriuretic peptides and inflammation: proteomic evidence obtained during acute cellular cardiac allograft rejection in humans. J Heart Lung Transplant 2008;27:31-37.

25 Houng AK, McNamee RA, Kerner A, Sharma P, Mohamad A, Tronolone J, Reed GL: Atrial natriuretic peptide increases inflammation, infarct size, and mortality after experimental coronary occlusion. Am J Physiol Heart Circ Physiol 2009;296:H655-H661.

26 Li CY, Chou TC, Lee CH, Tsai CS, Loh SH, Wong CS: Adrenaline inhibits lipopolysaccharide-induced macrophage inflammatory protein- $1 \alpha$ in human monocytes: the role of $\beta$-adrenergic receptors. Anesth Analg 2003;96:518-523.

27 Zuo L, Shi L, Yan F: The reciprocal interaction of sympathetic nervous system and cAMP-PKA-NF-кB pathway in immune suppression after experimental stroke. Neurosci Lett 2016;627:205-210.

28 Feitoza CQ Gonçalves GM, Semedo P, Cenedeze MA, Pinheiro HS, Beraldo FC, dos Santos OFP, Teixeira V de PA, dos Reis MA, Mazzali M, Pacheco-Silva A, Câmara NOS: Inhibition of COX 1 and 2 prior to renal ischemia/reperfusion injury decreases the development of fibrosis. Mol Med 2008;14:724-730.

29 Wang Y, Wang Y, Yang D, Yu X, Li H, Lv X, Lu D, Wang H: $\beta_{1}$-adrenoceptor stimulation promotes LPS-induced cardiomyocyte apoptosis through activating PKA and enhancing CaMKII and IкB $\alpha$ phosphorylation. Crit Care 2015;19:76.

30 Ikeda K, Nara Y, Yamori Y: Indirect systolic and mean blood pressure determination by a new tail cuff method in spontaneously hypertensive rats. Lab Anim 1991;25:26-29.

31 Krege JH, Hodgin JB, Hagaman JR, Smithies O: A noninvasive computerized tail-cuff system for measuring blood pressure in mice. Hypertension 1995;25:1111-1115.

32 Meneton P, Ichikawa I, Inagami T, Schnermann J: Renal physiology of the mouse. Am J Physiol Renal Physiol 2000;278:F339-F351.

33 Wang Y, Ragg H: An unexpected link between angiotensinogen and thrombin. FEBS Lett 2011;585:23952399.

34 Oliveira-Junior SA, Martinez PF, Guizoni DM, Campos DHS, Fernandes T, Oliveira EM, Okoshi MP, Okoshi K, Padovani CR, Cicogna AC: AT1 receptor blockade attenuates insulin resistance and myocardial remodeling in rats with diet-induced obesity. PloS One 2014;9:e86447. 


\section{Cellular Physiology Cell Physiol Biochem 2019;53:587-605 \begin{tabular}{l|l|l} 
and Binch 2019 The Author(s). Published by \\
\hline
\end{tabular} and BiOChemistry Published online: 20 September 2019 Cell Physiol Biochem Press GmbH\&Co. KG \\ Panico et al.: Cardiac Inflammation After Renal Ischemia}

35 Guberman C, Jellyman JK, Han G, Ross MG, Desai M: Maternal high-fat diet programs rat offspring hypertension and activates the adipose renin-angiotensin system. Am J Obstet Gynecol 2013;209:262. e1-262.e8.

36 Li C, Culver SA, Quadri S, Ledford KL, Al-Share QY, Ghadieh HE, Najjar SM, Siragy HM: High-fat diet amplifies renal renin angiotensin system expression, blood pressure elevation, and renal dysfunction caused by ceacam1 null deletion. Am J Physiol Endocrinol Metab 2015;309:E802-E810.

37 Wojnicz A, Ortiz JA, Casas AI, Freitas AE, López MG, Ruiz-Nuño A: Data supporting the rat brain sample preparation and validation assays for simultaneous determination of 8 neurotransmitters and their metabolites using liquid chromatography-tandem mass spectrometry. Data Brief 2016;7:714-720.

38 Mishra AK, Mishra A, Chattopadhyay P: A reversed-phase high performance liquid chromatographic method for determination of epinephrine in pharmaceutical formulation. Arch Appl Sci Res 2010;2:251256.

39 Muzi-Filho H, Bezerra CGP, Souza AM, Boldrini LC, Takiya CM, Oliveira FL, Nesi RT, Valença SS, EinickerLamas M, Vieyra A, Lara LS, Cunha VMN: Undernutrition affects cell survival, oxidative stress, $\mathrm{Ca}^{2+}$ handling and signaling pathways in vas deferens, crippling reproductive capacity. PloS One 2013;8:e69682.

40 Silva PA, Monnerat-Cahli G, Pereira-Acácio A, Luzardo R, Sampaio LS, Luna-Leite MA, Lara LS, EinickerLamas M, Panizzutti R, Madeira C, Vieira-Filho LD, Castro-Chaves C, Ribeiro VS, Paixão ADO, Medei E, Vieyra A: Mechanisms involving Ang II and MAPK/ERK1/2 signaling pathways underlie cardiac and renal alterations during chronic undernutrition. PloS One 2014;9:e100410.

41 Muzi-Filho H, Souza AM, Bezerra CGP, Boldrini LC, Takiya CM, Oliveira FL, Nesi RT, Valença SS, Silva AM, Zapata-Sudo G, Sudo RT, Einicker-Lamas M, Vieyra A, Lara LS, Cunha VMN: Rats undernourished in utero have altered $\mathrm{Ca}^{2+}$ signaling and reduced fertility in adulthood. Physiol Rep 2015;3:e12587.

42 Festing MFW, Altman DG: Guidelines for the design and statistical analysis of experiments using laboratory animals. ILAR Journal 2002;4:244-258.

43 Charan J, Kantharia ND: How to calculate sample size in animal studies? J Pharmacol Pharmacother 2013;4:303-306.

44 Dell RB, Holleran S, Ramakrishnan R: Sample size determination. ILAR J 2002;43:207-213.

45 Vansthertem D, Gossiaux A, Declèves AE, Caron N, Nonclercq D, Legrand A, Toubeau G: Expression of nestin, vimentin, and NCAM by renal interstitial cells after ischemic tubular injury. J Biomed Biotechnol 2010;2010:93259.

46 Toubeau G, Nonclercq D, Zanen J, Laurent G, Schaudies PR, Heuson-Stiennon JA: Renal tissue expression of EGF and EGF receptor after ischaemic tubular injury: an immunohistochemical study. Exp Nephrol 1994;2:229-239.

47 Witzgall R, Brown D, Schwarz C, Bonventre JV: Localization of proliferating cell nuclear antigen, vimentin, c-Fos, and clusterin in the postischemic kidney. Evidence for a heterogenous genetic response among nephron segments, and a large pool of mitotically active and dedifferentiated cells. J Clin Invest 1994;93:2175-2188.

48 Madamanchi A: $\beta$-adrenergic receptor signaling in cardiac function and heart failure. McGill J Med 2007;10:99-104.

49 Machackova J, Sanganalmath SK, Elimban V, Dhalla NS: $\beta$-adrenergic blockade attenuates cardiac dysfunction and myofibrillar remodelling in congestive heart failure. J Cell Mol Med 2011;15:545-554.

50 Prunotto A, Stevenson BJ, Berthonneche C, Schüpfer F, Beckmann JS, Maurer F, Bergmann S: RNAseq analysis of heart tissue from mice treated with atenolol and isoproterenol reveals a reciprocal transcriptional response. BMC Genomics 2016;17:717.

51 Lambert E, Schlaich M: The role of renal sympathetic nerves in ischemia reperfusion injury. Auton Neurosci 2017;204:105-111.

52 Tsutsui H, Tanaka R, Yamagata M, Yukimura T, Ohkita M, Matsumura Y: Protective effect of ischemic preconditioning on ischemia/reperfusion-induced acute kidney injury through sympathetic nervous system in rats. Eur J Pharmacol 2013;718:206-212.

53 Sata Y, Head GA, Denton K, May CN, Schlaich MP: Role of the sympathetic nervous system and its modulation in renal hypertension. Front Med (Lausanne) 2018;5:82.

54 Malpas SC, Leonard BL: Neural regulation of renal blood flow: a re-examination. Clin Exp Pharmacol Physiol 2000;27:956-964. 


\section{Cellular Physiology Cell Physiol Biochem 2019;53:587-605 \begin{tabular}{l|l|l}
\cline { 3 - 3 } DOI: 10.33594/000000159 & (c)19 The Author(s). Published by
\end{tabular} and BiOChemistry Published online: 20 September 2019 Cell Physiol Biochem Press GmbH\&Co. KG \\ Panico et al.: Cardiac Inflammation After Renal Ischemia}

55 Wenzel UO, Thaiss F, Helmchen U, Stahl RAK, Wolf G: Angiotensin II infusion ameliorates the early phase of a mesangioproliferative glomerulonephritis. Kidney Int 2002;61:1020-1029.

56 Hennington BS, Zhang H, Miller MT, Granger JP, Reckelhoff JF: Angiotensin II stimulates synthesis of endothelial nitric oxide synthase. Hypertension 1998;31:283-288.

57 Thorup C, Kornfeld M, Winaver JM, Goligorsky MS, Moore LC: Angiotensin-II stimulates nitric oxide release in isolated perfused renal resistance arteries. Pflügers Arch 1998;435:432-434.

58 Rodrigues-Ferreira S, Nahmias C: An atipical family of Angiotensin II AT 2 receptor-interacting proteins. Trends Endocrinol Metab 2010;21:684-690.

59 Zhong J, Guo D, Chen CB, Wang W, Schuster M, Loibner H, Penninger JM, Scholey JW, Kassiri Z, Oudit GY: Prevention of angiotensin II-mediated renal oxidative stress, inflammation, and fibrosis by angiotensinconverting enzyme 2. Hypertension 2011; 57:314-322.

60 Zhuo JL, Li XC: New insights and perspectives on intrarenal renin-angiotensin system: focus on intracrine/ intracellular angiotensin II. Peptides 2011;32:1551-1565.

61 Williams VR, Scholey JW: Angiotensin-converting enzyme 2 and renal disease. Curr Opin Nephrol Hypertens 2018;27:35-41.

62 Santos RAS, Oudit GY, Verano-Braga T, Canta G, Steckelings UM, Bader M: The renin-angiotensin system: going beyond the classical paradigms. Am J Physiol Heart Circ Physiol 2019;316:H958-H970.

63 Machackova J, Sanganalmath SK, Barta J, Dhalla KS, Dhalla NS: Amelioration of cardiac remodeling in congestive heart failure by $\beta$-adrenoceptor blockade is associated with depression in sympathetic activity. Cardiovasc Toxicol 2010;10:9-16.

64 Dai W, Kloner RA: Potential role of renin-angiotensin system blockade for preventing myocardial ischemia/ reperfusion injury and remodeling after myocardial infarction. Postgrad Med 2011;123:49-55.

65 Matsubara H, Hirata Y, Yoshimi H, Takata S, Takagi Y, Umeda Y, Yamane Y, Inada M: Role of calcium and protein kinase $\mathrm{C}$ in ANP secretion by cultured rat cardiocytes. Am J Physiol Heart Circ Physiol 1988;255:H405-H409.

66 Dostal DE, Baker KM: The cardiac renin-angiotensin system: conceptual, or a regulator of cardiac function? Circ Res 1999;85:643-650.

67 De Angelis E, Pecoraro M, Rusciano MR, Ciccarelli M, Popolo A: Cross-talk between neurohormonal pathways and the immune system in heart failure: a review of the Literature. Int J Mol Sci 2019;20:1698.

68 Remme WJ, de Leeuw PW, Bootsma M, Look MP, Kruijssen DACM: Systemic neurohumoral activation and vasoconstriction during pacing-induced acute myocardial ischemia in patients with stable angina pectoris. Am J Cardiol 1991;68:181-186.

69 Remme WJ, Kruyssen DACM, Look MP, Bootsma M, de Leeuw PW: Systemic and cardiac neuroendocrine activation and severity of myocardial ischemia in humans. J Am Coll Cardiol 1994;23:82-91.

70 Slavíková J, Kuncová J, Topolčan 0: Plasma catecholamines and ischemic heart disease. Clin Cardiol 2007;30:326-330.

71 McPherson GA, Molenaar P, Malta E: The affinity and efficacy of naturally occurring catecholamines at $\beta$-adrenoceptor subtypes. J Pharm Pharmacol 1985;37:499-501.

72 Kohli U, Grayson BL, Aune TM, Ghimire LV, Kurnik D, Stein CM: Change in mRNA expression after atenolol, a beta-adrenergic receptor antagonist and association with pharmacological response. Arch Drug Inf 2009;2:41-50.

73 Abreu RS, Penalva LO, Marcotte EM, Vogel C: Global signatures of protein and mRNA expression levels. Mol Biosyst 2009;5:1512-1526.

74 Maier T, Güell M, Serrano L: Correlation of mRNA and protein in complex biological samples. FEBS Lett 2009;583:3966-3973.

75 Daemen MARC, van de Ven MWCM, Heineman E, Buurman WA: Involvement of endogenous interleukin-10 and tumor necrosis factor- $\alpha$ in renal ischemia-reperfusion injury. Transplantation 1999;67:792-800.

76 Gurantz D, Cowling RT, Villarreal FJ, Greenberg BH: Tumor necrosis factor- $\alpha$ upregulates angiotensin II type 1 receptors on cardiac fibroblasts. Circ Res 1999;85:272-279.

77 Goldsmith SR: Interactions between the sympathetic nervous system and the RAAS in heart failure. Curr Heart Fail Rep 2004;1:45-50.

78 Jan Danser AH, Saris JJ: Prorenin uptake in the heart: a prerequisite for local angiotensin generation? J Mol Cell Cardiol 2002;34:1463-1472. 


\section{Cellular Physiology and Biochemistry}

Cell Physiol Biochem 2019;53:587-605

\begin{tabular}{l|l}
\hline DOI: 10.33594/000000159 & ( 2019 The Author(s). Published by
\end{tabular}

Panico et al.: Cardiac Inflammation After Renal Ischemia

79 Paul M, Poyan Mehr A, Kreutz R: Physiology of local renin-angiotensin systems. Physiol Rev 2006;86:747803.

80 Brøchner AC, Dagnæs-Hansen F, Højberg-Holm J, Toft P: The inflammatory response in blood and in remote organs following acute kidney injury. APMIS 2014;122:399-404.

81 Park SW, Kim M, Brown KM, D’Agati VD, Lee HT: Paneth cell-derived interleukin-17A causes multiorgan dysfunction after hepatic ischemia and reperfusion injury. Hepatology 2011;53:1662-1675.

82 Liu M, Liang Y, Chigurupati S, Lathia JD, Pletnikov M, Sun Z, Crow M, Ross CA, Mattson MP, Rabb H: Acute kidney injury leads to inflammation and functional changes in the brain. J Am Soc Nephrol 2008;19:13601370.

83 Kelly KJ: Distant effects of experimental renal ischemia/reperfusion injury. J Am Soc Nephrol 2003;14:1549-1558.

84 Doi K, Rabb H: Impact of acute kidney injury on distant organ function: recent findings and potential therapeutic targets. Kidney Int 2016;89:555-564.

85 Kanda T, Takahashi T: Interleukin-6 and cardiovascular diseases. Jpn Heart J 2004;45:183-193.

86 Prabhu SD, Chandrasekar B, Murray DR, Freeman GL: $\beta$-adrenergic blockade in developing heart failure: effects on myocardial inflammatory cytokines, nitric oxide, and remodeling. Circulation 2000;101:21032109.

87 Kalra D, Sivasubramanian N, Mann DL: Angiotensin II induces tumor necrosis factor biosynthesis in the adult mammalian heart through a protein kinase C-dependent pathway. Circulation 2002;105:2198-2205.

88 Kenney MJ, Ganta CK: Autonomic nervous system and immune system interactions. Compr Physiol 2014;4:1177-1200.

89 Ruiz-Ortega M, Ruperez M, Lorenzo O, Esteban V, Blanco J, Mezzano S, Egido J: Angiotensin II regulates the synthesis of proinflammatory cytokines and chemokines in the kidney. Kidney Int 2002;62:S12-S22.

90 Ahn J, Varagic J, Slama M, Susic D, Frohlich ED: Cardiac structural and functional responses to salt loading in SHR. Am J Physiol Heart Circ Physiol 2004;287:H767-H772.

91 Cuspidi C, Facchetti R, Bombelli M, Tadic M, Sala C, Grassi G, Mancia G: High normal blood pressure and left ventricular hypertrophy echocardiographic findings from the PAMELA population. Hypertension 2019;73:612-619.

92 Du Cailar G, Ribstein J, Daures J-P, Mimran A: Sodium and left ventricular mass in untreated hypertensive and normotensive subjects. Am J Physiol 1992;263:H177-H181.

93 Takeda Y, Yoneda T, Demura M, Miyamori I, Mabuchi H: Sodium-induced cardiac aldosterone synthesis causes cardiac hypertrophy. Endocrinology 2000;141:1901-1904.

94 Ferreira DN, Katayama IA, Oliveira IB, Rosa KT, Furukawa LNS, Coelho MS, Casarini DE, Heimann JC: Saltinduced cardiac hypertrophy and interstitial fibrosis are due to a blood pressure-independent mechanism in Wistar rats. J Nutr 2010;140:1742-1751.

95 Bacchus R, Singh K, Ogeer I, Mungrue K: The occurrence of left ventricular hypertrophy in normotensive individuals in a community setting in North-East Trinidad. Vasc Health Risk Manag 2011;7:327-332.

96 Singh MV, Cicha MZ, Nunez S, Meyerholz DK, Chapleau MW, Abboud FM: Angiotensin II-induced hypertension and cardiac hypertrophy are differentially mediated by TLR3- and TLR4-dependent pathways. Am J Physiol Heart Circ Physiol 2019;316:H1027-H1038. 